\title{
Computed tomographic anatomy of the larynx in mesaticephalic dogs
}

\author{
Tomografía computarizada de la laringe en perros mesocefálicos \\ B Pérez ${ }^{\text {a }}$ M Gómez ${ }^{\text {a* }}$, M Mieres ${ }^{b}$, JS Galecio ${ }^{b}$, C Yefi $^{\text {a }}$, P Aburto ${ }^{a}$ \\ anstituto de Farmacología y Morfofisiología, Facultad de Ciencias Veterinarias, \\ Universidad Austral de Chile, Valdivia, Chile. \\ bInstituto de Ciencias Clínicas Veterinarias, Facultad de Ciencias Veterinarias, \\ Universidad Austral de Chile, Valdivia, Chile.
}

\begin{abstract}
RESUMEN
El objetivo de este trabajo fue describir mediante tomografía computarizada (TC) la anatomía normal de la laringe y sus estructuras anexas en perros mesocéfalos y además correlacionar las imágenes obtenidas con cortes anatómicos. Para ello se utilizaron dos perros adultos sin signos de alteraciones respiratorias con pesos de 12,8 a 18,5 kg respectivamente. En ambos animales se obtuvieron imágenes de TC a nivel de la laringe, bajo anestesia general y con los animales posicionados en decúbito dorsal. Los parámetros técnicos incluyeron imágenes de $3 \mathrm{~mm}$ de grosor y 2 mm de intervalo y utilizando una ventana para tejidos blandos. Posteriormente las imágenes obtenidas fueron correlacionadas con secciones anatómicas. La cavidad central de la laringe que incluye el vestíbulo laríngeo, glotis y cavidad infraglótica fue observada como un área hipodensa en todas las imágenes. Otros espacios también identificados incluyeron los recesos piriformes, la vallécula epiglótica y los ventrículos laríngeos. Los cartílagos tiroides y cricoides fueron claramente distinguidos como estructuras lineares hiperdensas, mientras que los cartílagos aritenoideos no se observaron nítidamente debido a la poca calcificación de estos cartílagos observada en los perros. La epiglotis fue identificada como una estructura central cóncava e isodensa. Los resultados obtenidos indican que la TC es un excelente método para evaluación imagenológica de la compleja anatomía de la laringe en perros.
\end{abstract}

Key words: computed tomography, larynx, dogs.

Palabras clave: tomografía computarizada, laringe, perro.

\section{INTRODUCTION}

Computed tomography (CT) has been used in the analysis of different anatomic areas of the head and neck in dogs (Fike 1981, Feeney 1991, Thomas 1992, Assheuer 1997, De Rycke 2003). However, few publications include a detailed imaging analysis focus on the laryngeal area (Feeney et al 1991, Assahauer et al 1997, Vasquez et al 1997). In humans, CT and MRI are procedures of choice to injuries of the larynx and surrounding tissue including cartilaginous lacerations, fractures and avulsion, laryngeal and perilaryngeal inflammation, laryngeal nerve paralysis, cyst and laryngoceles, soft tissue hematomas and neoplasms (Bergman et al 1979, Maffe 1984, Newell et al 1996, Becker et al 2008). Additionally, the canine larynx has been used as an appropriate animal model for human laryngeal studies because of their similarity in size and gross structure (Moon et al 2004). Nevertheless, before studying laryngeal disorders using $\mathrm{CT}$, the normal anatomy of laryngeal and perilaryngeal structures must be established with this modality. We therefore performed an imaging as well as an anatomic study of the canine larynx and its associated soft tissue.

Accepted: 29.07.2009.

* Casilla 567, Valdivia, Chile; marcelogomez@uach.cl

\section{MATERIAL AND METHODS}

ANIMALS

This study was performed in 2 young-adult mixed breed dogs. Dogs weighed 12.8 and $18.5 \mathrm{~kg}$ respectively. Dogs were clinically normal and no respiratory abnormalities were found on physical examination. All procedures were approved by the Universidad Austral de Chile Institutional Animal Care and Use Committee.

\section{CT STUDY}

Dogs were fasted for 6 hours and then anaesthetized using ketamine $\left(5 \mathrm{mg} / \mathrm{kg}\right.$, IV) (Ketostop ${ }^{\circledR}$, Laboratorio Drag Pharma) and diazepam ( $0.1 \mathrm{mg} / \mathrm{kg}$, IV) (Diazepam ${ }^{\circledR}$, Laboratorio Biosano). Computed tomographic examinations were performed using a fourth generation $\mathrm{CT}$ scanner (Picker 4000, Medical System, Ohio, USA). Transverse sections were made with slice thickness of $3 \mathrm{~mm}$ and a $2 \mathrm{~mm}$ interval. Dogs were placed in dorsal recumbency with the neck extended. Thoracic limbs were pulled caudally and slight traction force was maintained using duct tape. Radiolucent sponges were used to maintain the correct position of the head during the investigation. The technical parameters were $130 \mathrm{Kv}, 85 \mathrm{~mA}, 178 \mathrm{mAs}$. Images were obtained using a soft tissue window (Window Level:100 Hounsfield units Window Width:300 Hounsfield units). 
After an initial plan view the region under investigation extended from to the third cervical vertebrae.

\section{ANATOMIC STUDY}

After CT images were obtained, dogs were euthanized using an overdose of Sodium Thiopental $(1000 \mathrm{mg})$ (Tiopental sódico ${ }^{\circledR}$, Laboratorio Richmond Vet). Cadavers were positioned in dorsal recumbency over a wooden base platform $(50 \times 100 \mathrm{~cm})$ with the neck in an extended position. Then, animals were frozen at $-20 \mathrm{C}^{\mathrm{o}}$ for one week in the same positioning used in the $\mathrm{CT}$ examination. The cadavers were then cut at $2 \mathrm{~mm}$ thick slices using a circular band saw in planes parallel to those of the CT scans. Anatomical tissue sections were later photographed from both sides and then compared and correlated with corresponding CT images. The terminology in this study is in accordance with the Nomina Anatomica Veterinaria (WAVA 2005).

\section{RESULTS AND DISCUSSION}

A total of 18 anatomical transverse sections were obtained from each dog and compared with the corresponding CT sections (figure 1). Figure 2 to figure 7 represent the most representative CT images obtained. From each image the laryngeal and perilaryngeal structures were studied. Images are shown from cranial to caudal indicating the detail of the laryngeal structures. An additional scheme is shown to facilitate the level of the transverse image. On each image the laryngeal and perilaryngeal structures were studied.

In both animals the central cavity of the larynx including laryngeal vestibule, glottis and infraglottic cavity were visible as hypodense spaces (figure 2 to 7 ). At the level of the vocal muscles the glottis was observed as a narrow elliptical cavity similar to observations reported in human CT studies (Gamsu et al 1981). Inside the cricoid cartilage

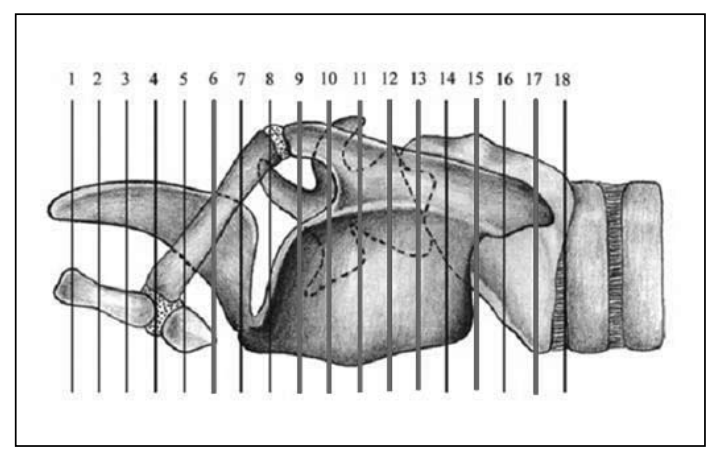

Figure 1. Schematic representation of the canine larynx indicating the level of anatomic (A) and CT sections (B). Corresponding section of CT images and anatomic section are illustrated from figures 2 to figure 9 .

Representación esquemática de la laringe canina indicando el nivel anatómico (A) y sección de TC (B). Las imágenes anatómicas y TC correspondientes son ilustradas desde la figura 2 a la figura 9. the laryngeal cavity was observed as a vertical oval shaped area with smooth margins (figure 7). In more caudal CT images, the laryngeal cavity had a more round shape similar to the tracheal lumen. Narrowing of the lumen of the larynx in dogs can occur due to laryngeal collapse by cricoid cartilage fracture, laryngeal paralysis or masses (Rudorf y Brown 1998, Rudorf et al 2001, Francis et al 2008). Other laryngeal spaces that were also identified included the epiglottic vallecula, the piriform recess, and the lateral ventricles (figure 2, 3 and 4). The epiglottic vallecula consists of two deep depressions located between the base of the tongue and the lingual face of the epiglottis (Evans 1993). On CT images the epiglottic vallecula was observed as large hypodense asymmetric elliptic spaces (figure 2). Other authors described a similar appearance in human CT images of the larynx (Korobkin 1983, Mafee 1984).

The epiglottic cartilage was observed as a hypodense structure (11-15 HU) due to its low calcification in these young specimens (figure 2). Our observations are in agreement with those described in humans (Maffe 1984). However, the epiglottic cartilage in humans exhibits a progressive calcification with age (Kano et al 2005). There is no information in the literature about aging changes of the elastic cartilage of the larynx in dogs. In cranial sections, the epiglottic cartilage was $U$ shaped and then become a more V shape caudally (figure 2 ). In humans, the epiglottis is described as an anteriorly concave structure throughout its length (Bergman et al 1979, Maffe 1984). In the case of pre-epiglottic extension of tumours, apart from the increased density of the pre-epiglottic space, the anteriorly concave, curved image of the epiglottis may be reversed (reverse epiglottic sign) in humans (Maffe 1984). The paired arytenoid cartilages were observed as two triangular or "coma" shaped symmetric and isodense structures with little evidence of calcification (figure 3). Vocal processes were observed as soft tissue density running from the vocal process of the arytenoid cartilage to the base of the thyroid cartilage. Density of the arytenoid cartilage was about 50 HU. In humans, the epiglottic cartilage and the arytenoid cartilage are originally formed by hyaline cartilage but later elastic fibers are deposit into the matrix turning them into yellow elastic cartilage that rarely calcifies (Maffe 1984).

The thyroid cartilage showed a U shape with a dorsal opening (figure 4). In humans, some authors described a similar shape, however other reports described that sometimes the thyroid lamina forms a more acute angle (Archer 1979, Gamsu 1981). In some cases, this appearance can be confused with collapse of the cartilage due to tumor invasion (Archer 1979). The thickness of the thyroid lamina in our dogs decreased from cranial to caudal contrary to the findings in humans. Rostral horns of the thyroid cartilage were observed as 2 slightly hyperdense (80-120 HU) round areas dorsolateral to the piriform recess (figure 3 ). CT studies on humans have described these as circular and hyperdense structures (Bergman 1979). In our study, these young dogs showed partial areas of calcification mainly in 


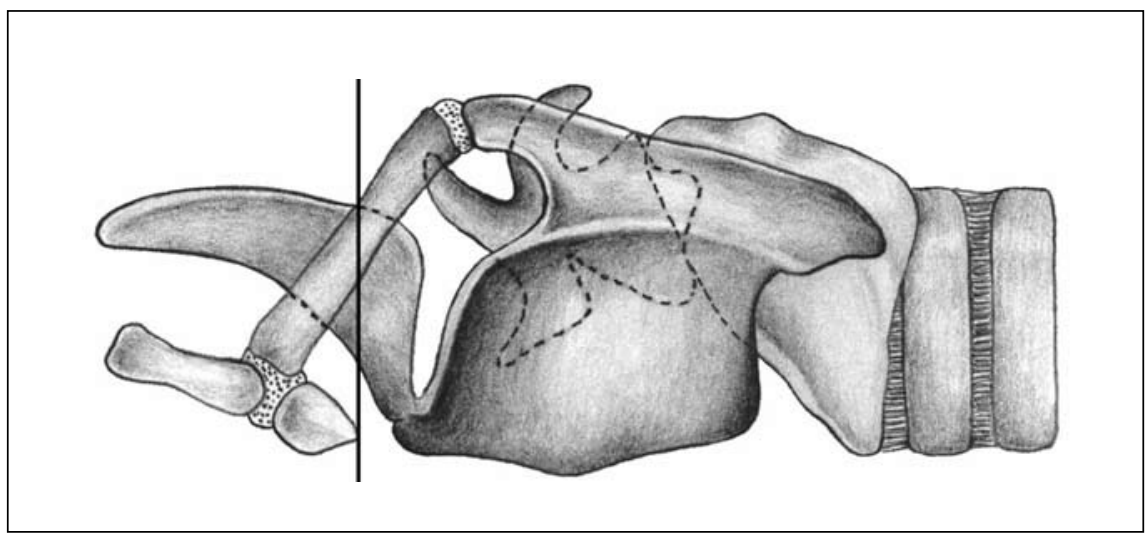

$\mathbf{A}$

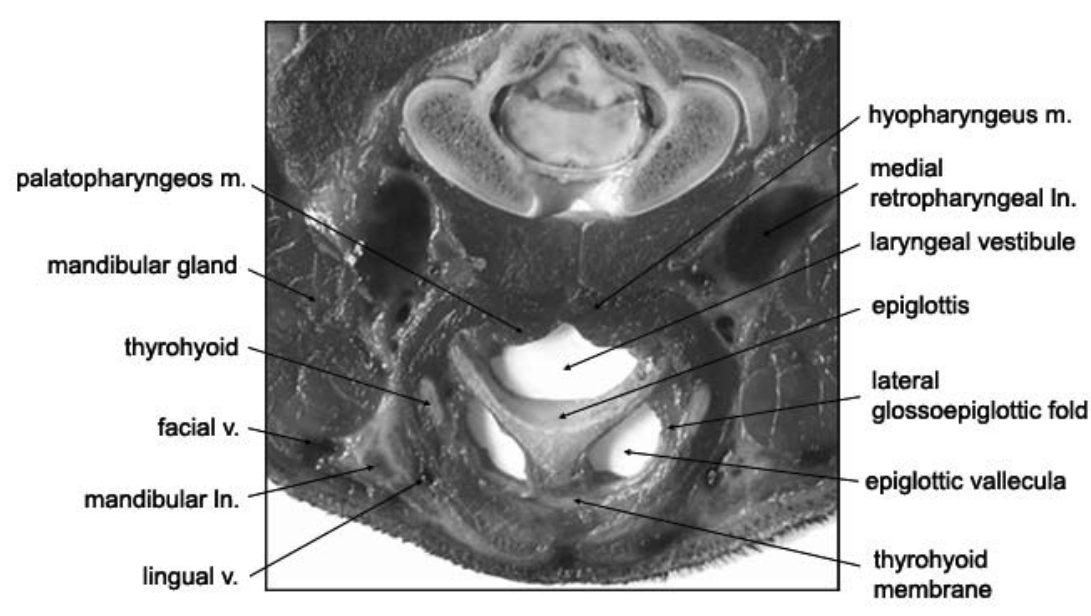

B

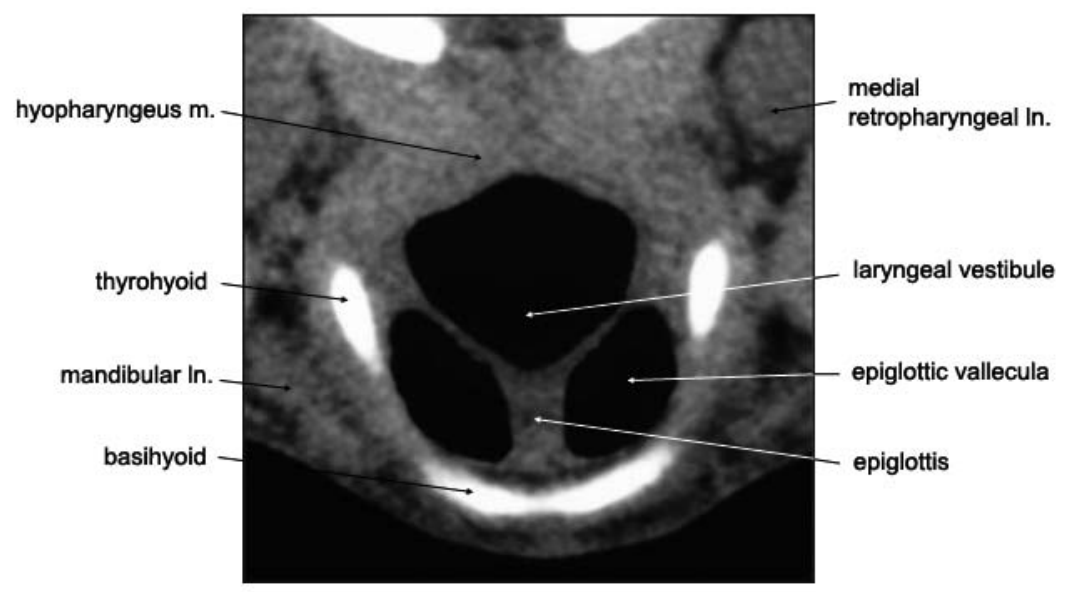

Figure 2. Anatomic section (A) and CT image (B) of the canine larynx at the section level 6 of the figure 1 . Sección anatómica (A) e imagen TC (B) de la laringe canina correspondiente al nivel 6 de la figura 1. 


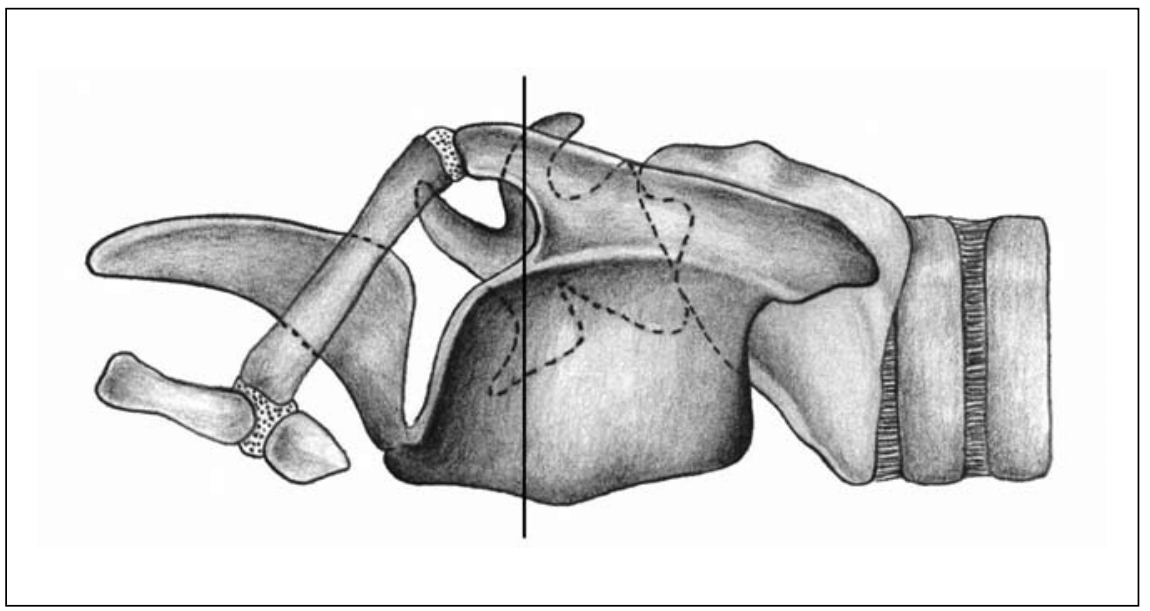

A

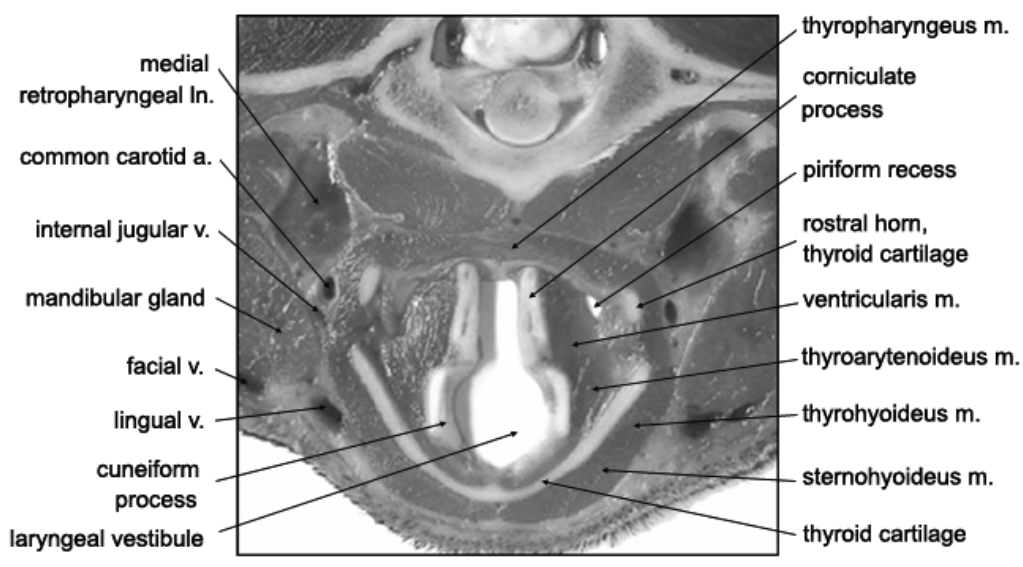

B

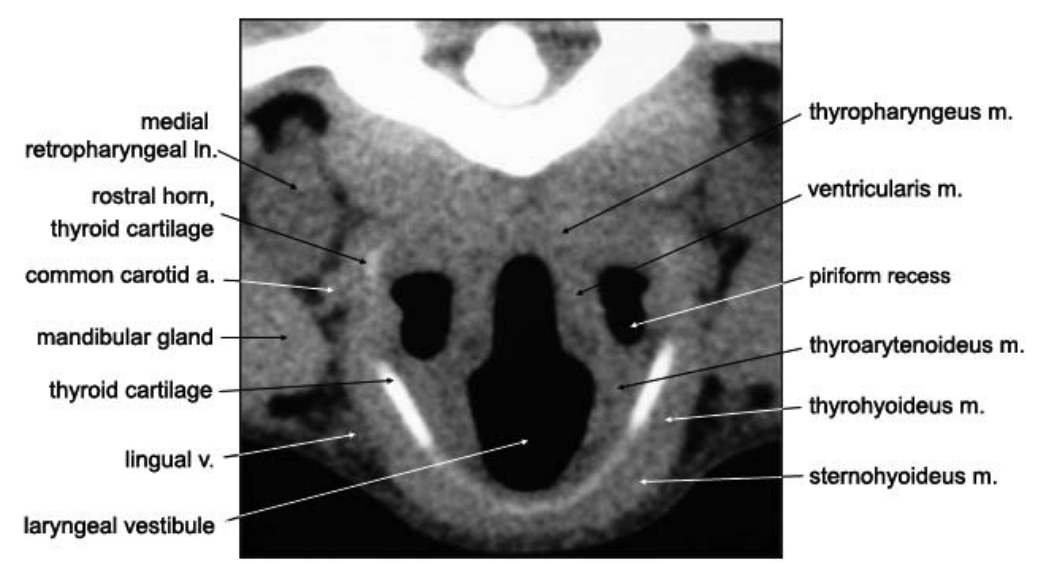

Figure 3. Anatomic section (A) and CT image (B) of the canine larynx at the section level 10 of the figure 1. Sección anatómica (A) e imagen TC (B) de la laringe canina correspondiente al nivel 10 de la figura 1. 


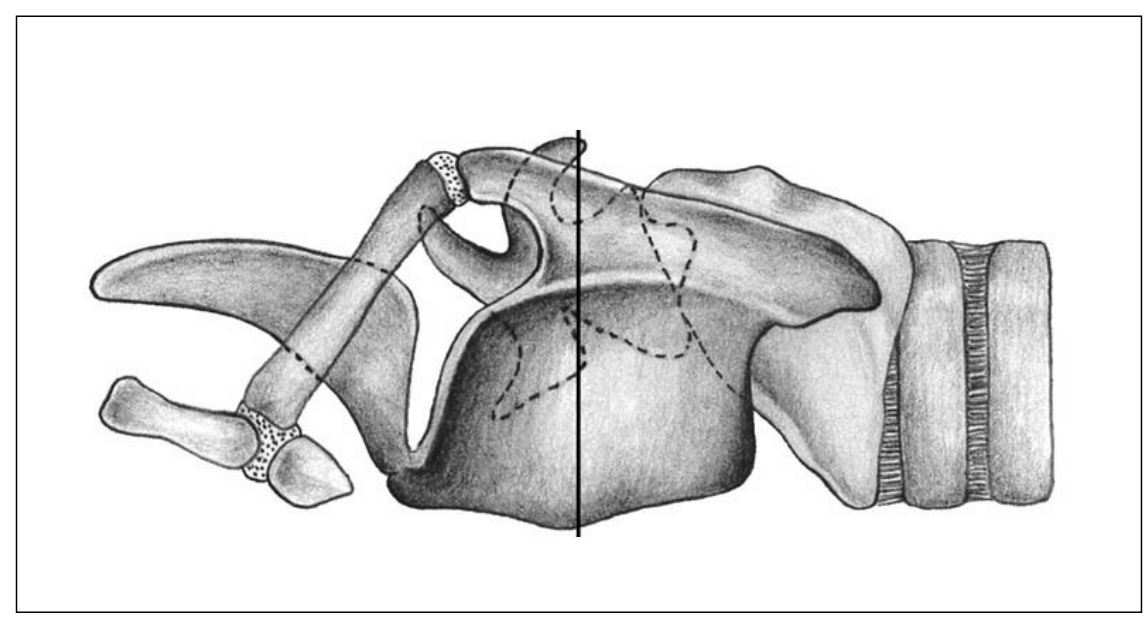

A

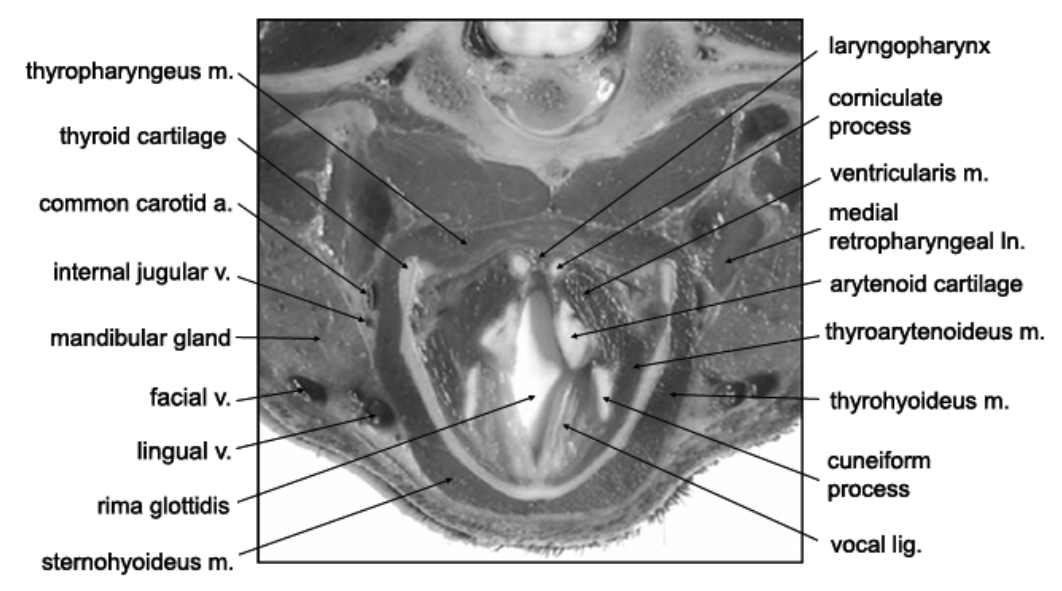

B

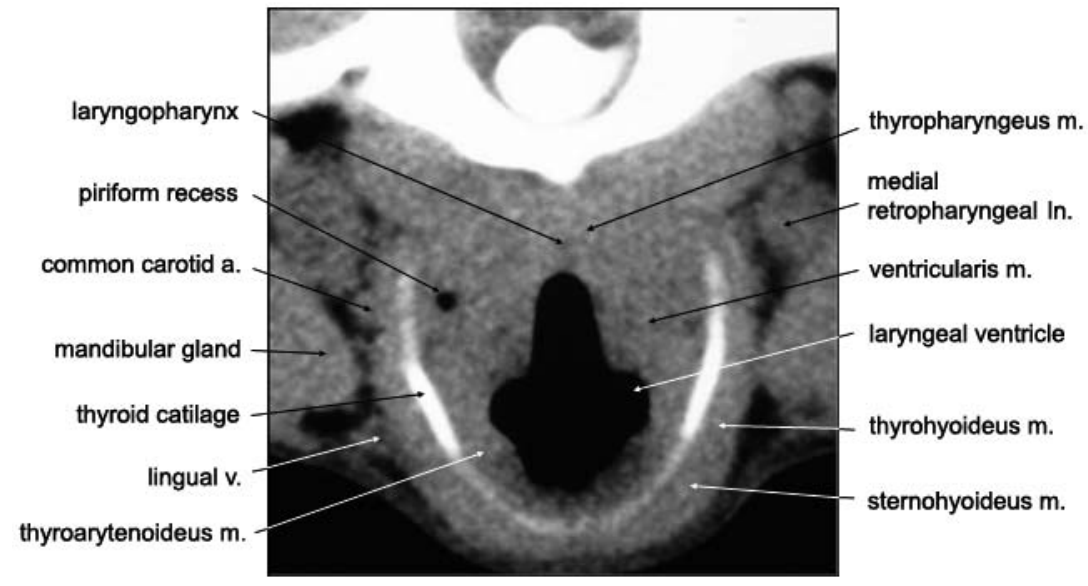

Figure 4. Anatomic section (A) and CT image (B) of the canine larynx at the section level 11 of the figure 1. Sección anatómica (A) e imagen TC (B) de la laringe canina correspondiente al nivel 11 de la figura 1. 


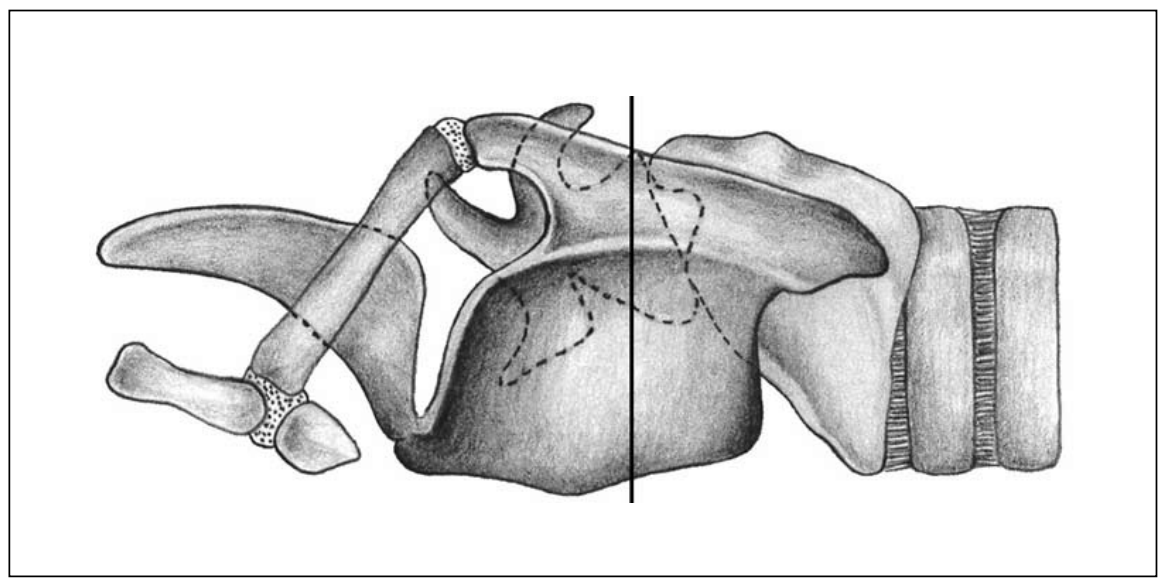

A

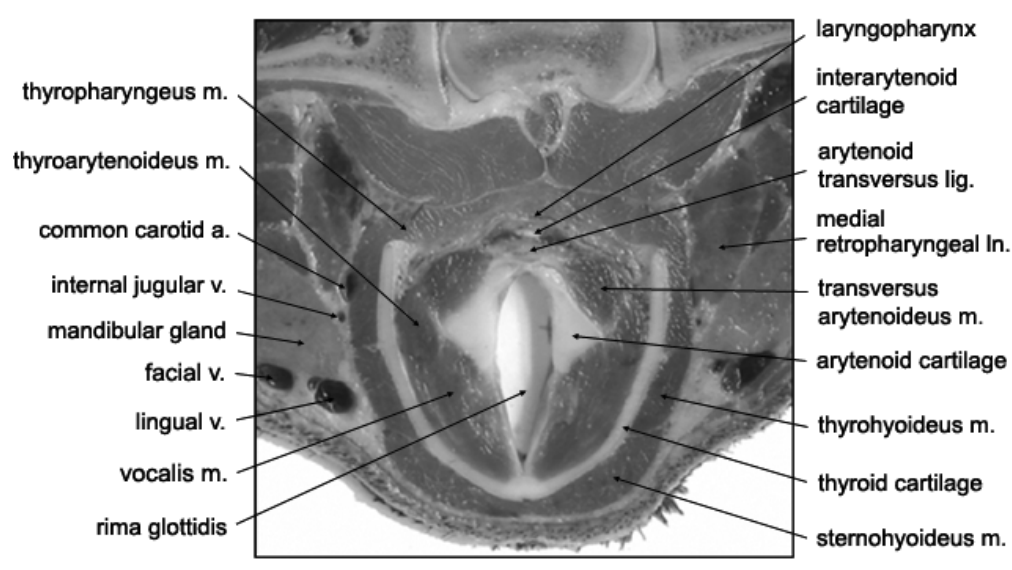

B

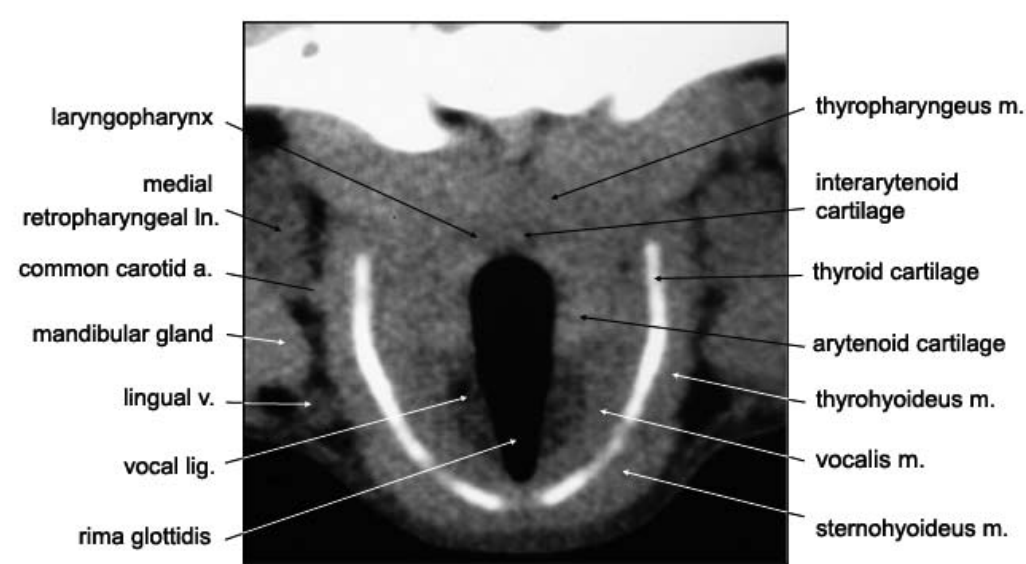

Figure 5. Anatomic section (A) and CT image (B) of the canine larynx at the section level 12 of the figure 1 . Sección anatómica (A) e imagen TC (B) de la laringe canina correspondiente al nivel 12 de la figura 1 
the body of the thyroid cartilage. In humans over 50 years old, two CT image patterns are reported (Gamsu 1981). The first pattern showed a peripheral calcification of the cartilage with a central area of low density and a second pattern showing a homogeneous calcification of the thyroid laminae. The average density of the thyroid cartilage for the rostral horns were between 89 and $129 \mathrm{HU}$, while the caudal horns have a density of 377 and $522 \mathrm{HU}$. In both dogs, the cricoid cartilage was observed as a curved hyperdense ring with average attenuation values of 297 HU (figure 7). The lamina of the thyroid cartilage and the arch of the cricoid cartilage are reported to appear as hipointense signal structure in MRI images of the larynx in dogs and humans due to their hyaline composition (Vásquez 1998, Becker et al 2008).

Other perilaryngeal structures also identified included the common carotid artery, external jugular vein, linguofacial vein, maxillary vein, mandibular and parotid salivary glands, mandibular lymph nodes (Vásquez 1998). Intrinsic musculature of the larynx was not identified individually; however, the dorsal cricoarytenoid muscle and the cricothyroid muscle were identified in some images (figure 6 and 7).

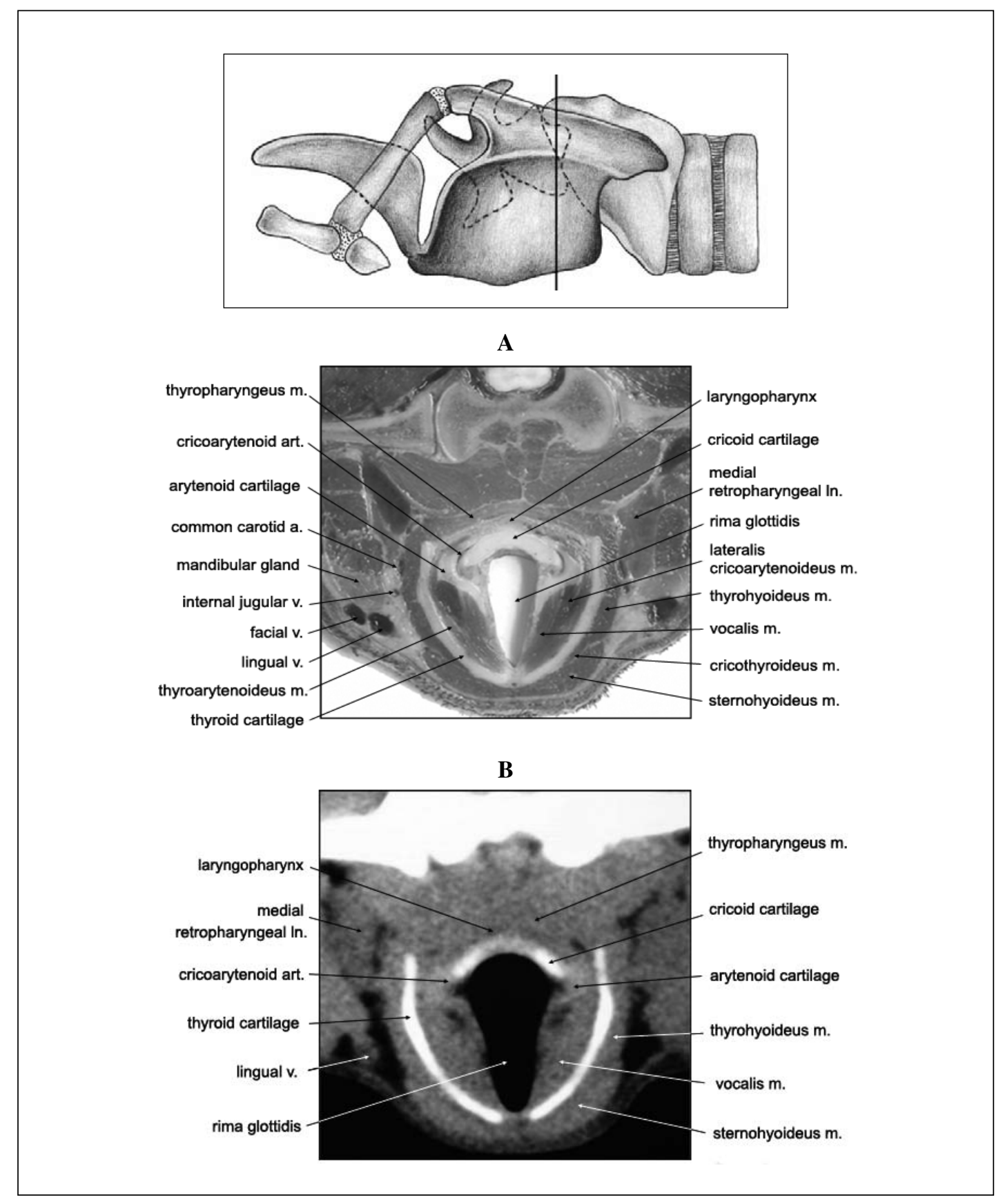

Figure 6. Anatomic section (A) and CT image (B) of the canine larynx at the section level 13 of the figure 1. Sección anatómica (A) e imagen TC (B) de la laringe canina correspondiente al nivel 13 de la figura 1. 


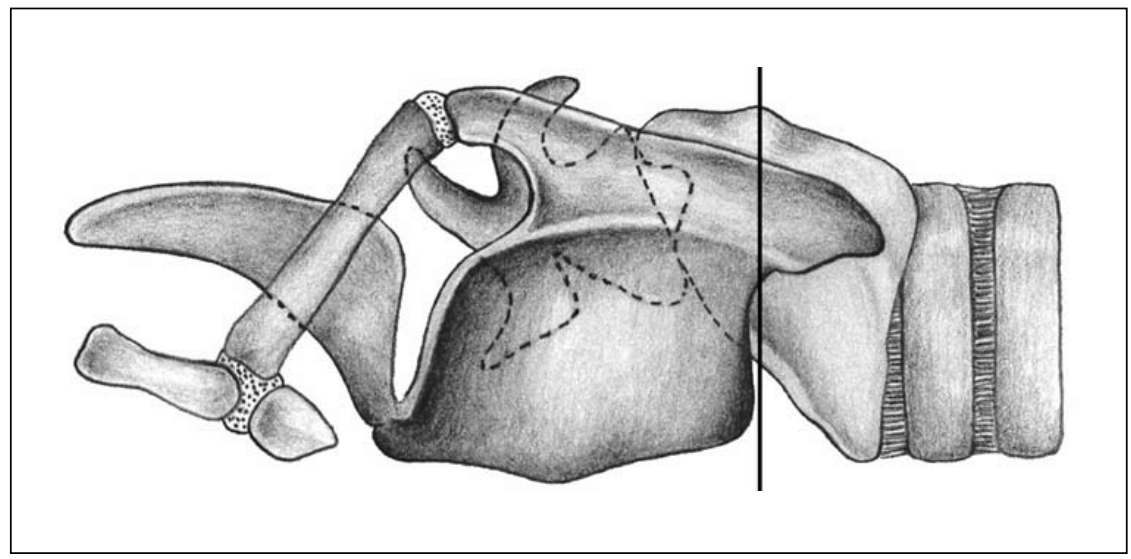

$\mathbf{A}$

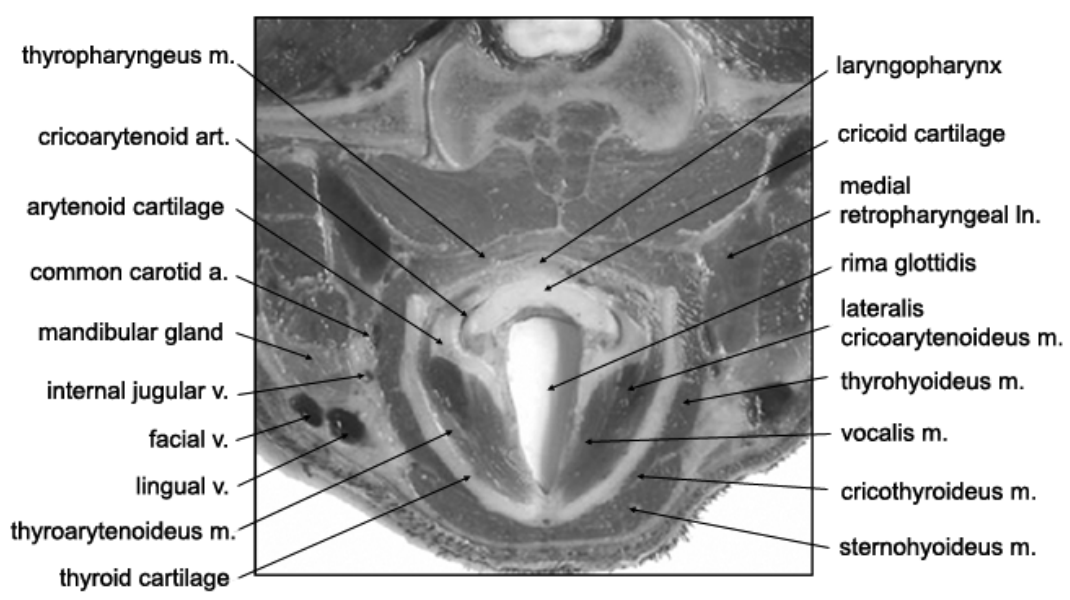

B

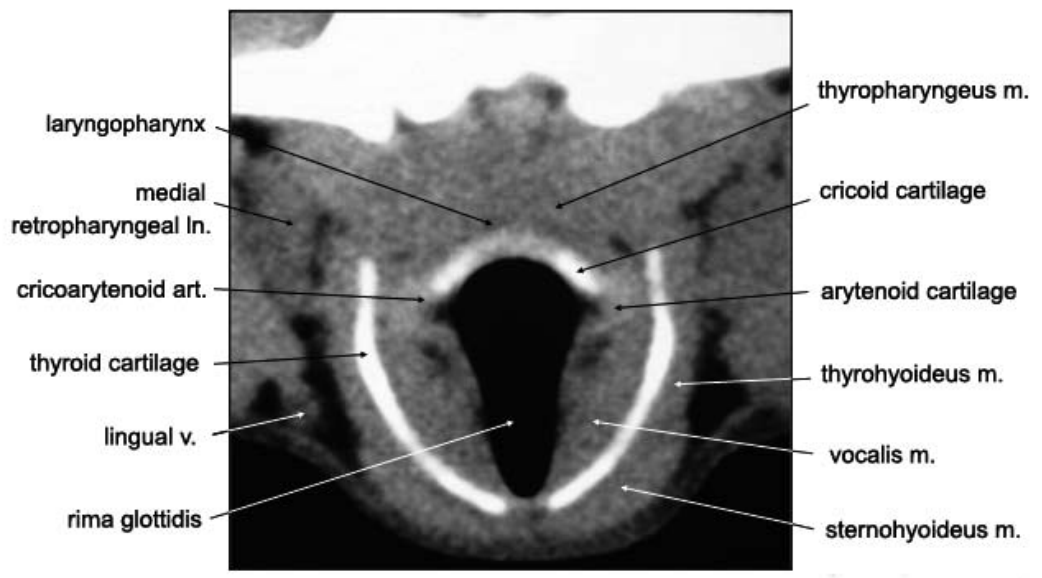

Figure 7. Anatomic section (A) and CT image (B) of the canine larynx at the section level 15 of the figure 1. Sección anatómica (A) e imagen TC (B) de la laringe canina correspondiente al nivel 15 de la figura 1. 
Demonstration of normal transverse laryngeal anatomy will help as a baseline for interpretation of pathological scans including tumor location, contours, size, extent; it will also help to clarify the relationship between the laryngeal pathologies and major vessels of the neck. It will help in determining cartilage invasion and also help in surgical and radiotheraphy treatment planning.

\section{SUMMARY}

The aim of this work was to describe the normal anatomy of the larynx and its adjacent structures in mesaticephalic dogs by computed tomographic (CT) images and correlate those with anatomical sections. For that, 2 clinically normal young-adult mesaticephalic dogs with body weight of $12.8 \mathrm{~kg}$ and $18.5 \mathrm{~kg}$, respectively were used. Computed tomography of the larynx was performed in 2 dogs under general anesthesia and in dorsal recumbency. Transverse images of the larynx with a slice thickness of $3 \mathrm{~mm}$ and a gap of $2 \mathrm{~mm}$ interval were obtained using a soft tissue window. CT images were correlated with anatomical cross-sections views. The central cavity of the larynx that includes the laryngeal vestibule, glottis and infraglottic cavities were observed as hypodense areas in all CT images. Other spaces also identified included the piriform recess, the epiglottic vallecula and the laryngeal ventricles. The thyroid and the cricoid cartilages were clearly represented as linear hyperdense structures. The arytenoid cartilages were only minimally calcified due to the young age of the animals therefore poorly seen on CT. The epiglottis was identified as a transverse concave isodense structure. Results indicated that CT provides an excellent method for imaging evaluation of the complex anatomy of the larynx in dogs.

\section{REFERENCES}

Archer CR, VL Yeager. 1979. Evaluation of laryngeal cartilages by computed tomography. J Comput Assist Tomogr 3, 604-611.

Assheuer J, M Sageer. 1997. Head. In: Assheuer J, Sager M (eds). MRI and CT atlas of the dog. Blackwell Science, Berlin, Germany, Pp 1-81.

Becker M, K Burkhardt, P Dulguerov, A Allal. 2008. Imaging of the larynx and hypopharynx. Eur J Radiol 66, 460-479.
Bergman AB, HL Neiman, RL Warpeha. 1979. Computed tomography of the larynx. Laryngoscope 89, 812-817.

De Rycke L, J Saunders, I Gielen, HJ van Bree, PJ Simoens. 2003. Magnetic resonance imaging, computed tomography, and cross sectional views of the anatomy of normal nasal cavities and paranasal sinuses in mesaticephalic dogs. Am J Vet Res 64, 1093-1098.

Evans HE. 1993. The respiratory system In: Anatomy of the dog. $3^{\text {rd }} \mathrm{ed}$. WS Saunders, Philadelphia, USA, Pp 472-479.

Feeney D, T Fletcher, R Hardy. 1991. Atlas of correlative imaging anatomy of the dog: ultrasound and computed tomography. WB Saunders, Philadelphia, USA.

Fike J, R LeCoteour, C Cann. 1981. Anatomy of the canine brain using high resolution computed tomography. Vet Radiol 22, 236-243.

Francis K, J Goggin, J Hoskinson. 2008. Laryngeal collapse due to cricoid cartilage fracture. Vet Radiol Ultrasound 49, 360-361.

Gamsu G, AS Mark, WR Webb. 1981. Computed tomography of the normal larynx during quiet breathing and phonation. J Comput Assist Tomogr 5, 353-360.

Kano M, Y Shimizu, K Okayama, T Igari, M Kikuchi. 2005. A morphometric study of age-related changes in adult human epiglottis using quantitative digital analysis of cartilage calcification. Cells Tissues Organs 180, 126-137.

Mafee MF. 1984. CT of the normal larynx. Radiol Clin North Am 22, 251-264.

Newell SM, MB Mahaffey, RE Roberts, AP Garcia, AR Stampley. Laryngeal adenocarcinoma in a dog. Vet Radiol Ultrasound 35, 217-220.

Rudorf H, P Brown. 1998. Ultrasonography of laryngeal masses in six cats and one dog. Vet Radiol Ultrasound 39, 430-435.

Rudorf H, FJ Barr, JG Lane. 2001. The role of ultrasound in the assessment of laryngeal paralysis in the dog. Vet Radiol Ultrasound 42, 338-342.

Silverman P, M Korobkin. 1983. High-resolution computed tomography of the normal larynx. Am J Roentgenol 140, 875-879.

Thomas G, J Smallwood. 1992. Anatomic atlas for computed tomography in mesaticephalic dog: Head and Neck. Vet Radiol Ultrasound 33, 217-240.

Vázquez JM, A Arancibia, F Gil, JA Ramírez, N González, CD Sosa, JR Jaber. 1998. Magnetic resonance imaging of the normal canine larynx. Anat Histol Embryol 27, 263-270.

WAVA, World Association of Veterinary Anatomists. 2005. Nomina anatomica veterinaria. $5^{\text {th }}$ ed. NY: International Committee on Veterinary Gross Anatomical Nomenclature, Ithaca, USA, Pp 1-198. 